\title{
MODEL PEMBELAJARAN GEOMETRI MENGGUNAKAN PENDEKATAN PENDIDIKAN MATEMATIKA REALISTIK INDONESIA (PMRI) DI SEKOLAH DASAR
}

\author{
Oleh : Syafri Ahmad / Mohamad Bin Bilal Ali \\ Email: syafriahmad95@yahoo.co.id / mba@utm.my \\ Universitas Negeri Padang / Universiti Teknologi Malaysia
}

\begin{abstract}
The phenomenon that often occurs in elementary school geometry teacher in the real world do not associate with students. Learning in the classroom is teacher-centered. The purpose of this study is to develop learning model geometry using realistic mathematics education approach (PMRI) are valid, practical, and effective. In addition, it also aims to see the difference between the students' learning outcomes geometry before and after using model geometry approach PMRI. This study was a research and development $(R \& D)$. For field trials used an experimental research design time series one-group pretest and posttest. Subjects were students in public elementary school no.14 Parak Laweh Padang four grade. The results showed that the learning model geometry with PMRI approaches that have been developed, as well as through experimental trials have been valid, practical, and effective. In sefesific there are differences in geometry student learning outcomes significantly between before and after using model geometry with PMRI approach. To the elementary school teacher suggested in learning geometry using learning model geometry PMRIapproach.
\end{abstract}

Keywords : Learning model, geometry, PMRI, van Hiele, elementary school.

\section{PENDAHULUAN}

Geometri merupakan salah satu cabang matematika yang diberikan di sekolah dasar mulai dari kelas satu sampai kelas enam. Geometri mempunyai kedudukan yang esensial di dalam kurikulum matematika sekolah, termasuk sekolah dasar. Begitu pula geometri merupakan salah satu topik yang sangat penting dalam matematika (Derbang Wu, 2005; French, 2004; Depdiknas, 2006; Marchis, 2012). Tambahan pula, seperti yang dijelaskan oleh Sa'dijah (2001) bahwa kanakkanak kita yang belajar di prasekolahpun sudah mempelajari geometri, meskipun masih bersifat sederhana dan bersifat informal. Mempelajari geometri dapat membangkitkan dan membangun kemampuan berfikir logis, membangun kemampuan ruang siswa, serta kemampuan menyelesaikan masalah dunia nyata dalam terminologi geometri (Jones \& Mooney, 2003; Presmeg, 2006; Nur'aeni, 2010). Pendapat tersebut selaras pula dengan pendedahan Kennedy (2008) bahawa"Rich experiences in geometry develop problem-solving and reasoning skill and connect with many other topics in mathematics and the real word". Sementara itu penjelasan yang sejalan pula Schwarzt, J.E (2008) mengemukakan bahwa aktifitas mempelajari dan mengeksplorasi geometri sangat baik untuk meningkatkan kemampuan siswa dalam berfikir logis dan menyelesaikan masalah. Geometri dapat dilihat sebagai tempat konsep yang menghubungkan dengan banyak tempat dalam domain matematika.

Nur'aeni (2010) menjelaskan lebih lanjut bahwa banyak konsep matematika yang dapat ditunjukkan atau dijelaskan dengan sajian gambar geometri. Bentuk geometri dapat dijumpai dengan mudah di sekitar kita, misalnya bentuk bangunan rumah, bangunan sekolah, kantor, surau atau masjid, papan tulis, meja, segitiga berwarna merah yang digunakan sopir truk atau mobil sewaktu rusak di jalan, dan sebagainya, sehingga model bentuk geometri sangat dekat dengan siswa usia sekolah dasar. Bahkan geometri ada dimana-mana seperti yang dipaparkan oleh Harun (2014) bahwa 
bahagian dari lingkungan yang terdapat di sekeliling kita apapun benda yang ada pasti memuat bentuk geometri. Tambahan lagi telah disadari bahwa geometri sangat membantu pelajar untuk memahami dunia sekitar, karena dunia sekitar penuh dengan bentuk-bentuk geometri. Begitu pula geometri dapat membantu siswa sekolah dasar untuk memahami, menggambarkan, atau mendeskripsikan benda-benda di sekitar mereka (Bell, Max et.al, 2004 ; Sa'dijah, 2001; Pitajeng, 2006).

Tambahan lagi seperti yang dijelaskan Sutawidjaja et al. (2001) bahwa salah satu alasan kenapa geometri diberikan di sekolah dasar karena geometri merupakan pengetahuan dasar yang harus dipelajari siswa. Para siswa dikehendaki memahami dan menguasai dengan baik mengenai konsep titik, garis, sudut, segitiga, persegi, persegi panjang, jajar genjang, lingkaran, kubus, balok, tabung, bola, pengukuran yang terhubungan dengan geometri datar dan geometri ruang, serta konsep-konsep geometri yang lain. Mengikut juga sebagai alasan lain bahawa konsep geometri sangat banyak digunakan dalam kehidupan keseharian pelajar. Erbas, A.K dan Yenmez, A.A (2011) menjelaskan pula bahwa geometri merupakan salah satu komponen utama dalam matematika sekolah, termasuk sekolah dasar. Dengan mengkaji geometri, siswa belajar tentang bentuk geometri, struktur serta bagaimana menganalisis ciri-ciri atau sifat-sifat dan hubungan mereka dan membangunkan kebolehan pemikiran logis, pemahaman spatial mengenai dunia sebenar, pengetahuan yang diperlukan untuk mengkaji lebih lanjut konsep matematika, dan kemahiran dalam membaca dan tafsiran berpikir matematika.

Penguasaan yang baik terhadap konsepkonsep geometri yang sudah disebut di atas perlu sejak dari sekolah dasar, karena dengan penguasaan yang baik itu akan membantu pelajar untuk mempelajari tajuk geometri yang sifatnya berlanjut di semua kelas dan di semua jenjang pendidikan yang lebih tinggi. Dalam hal ini misalnya dalam mempelajari konsep bidang koordinat kartesius, pencerminan atau reflektions, geseran atau translations, putaran atau rotations dan pembesaran/pengecilan atau dilatations ( Ahmad, 2013). Sementara itu Chang, K.E.et al.(2007) menjelaskan pula bahwa konsep geometri adalah sangat penting bagi pengajaran dan pembelajaran matematika di sekolah dasar.

Van de walle (2008) menjelaskan pula bahwa geometri memiliki peranan penting dalam mempelajari bidang matematika yang lain, misalnya konsep pecahan berhubungkait dengan susunan himpunan bahagian (part whole construct). Begitu pula konsep perbandingan (proportion) berhubungkait langsung dengan konsep persamaan geometri. Pengukuran dan geometri jelas merupakan tajuk yang saling berhubungan masing-masing membantu siswa dalam memahami tajuk yang lain. Bahkan kemampuan untuk dapat mendesain bangunan negara Indonesia pada masa yang akan datang sangat ditentukan oleh kualitas penguasaan dan pemahaman konsep geometri siswa sekolah dasar sejak waktusekarang (Sarjiman, 2012). Untuk dapat memahami dan menguasai secara baik terhadap konsep geometri ini diperlukan proses pembelajaran yang berkualitas baik diterapkan di sekolah dasar. Proses pembelajaran yang berkualitas baik dimaksudkan di sini adalah pembelajaran yang inovatif progresif yaitu suatu perubahan paradigma proses pembelajaran yang dulu berpusat pada guru (teacher centered) berpindah menjadi berpusat pada pelajar (student centered). Metodologi yang dulu lebih dinominasi ekspositori (ceramah) berganti ke partisipatori (keaktifan siswa), dan pendekatan yang dulu lebih banyak bersifat tekstual berubah menjadi kontekstual (Trianto, 2011).

Daryanto dan Muljo Rahardjo (2012) menjelaskan bahwa pendekatan kontekstual merupakan konsep belajar yang membantu guru menghubungkan antara tajuk yang diajarkan dengan situasi dunia nyata (konteks realistik) siswa dan mendorong siswa membuat hubungan antara pengetahuan yang dimilikinya dengan penerapannya dalam kehidupan sehari-hari serta dapat membangun dan menemukan sediri 
(reinvention) suatu konsep yang diberikan. Dalam kurikulum KTSP (2006) pada mata pelajaran matematika (termasuk tajuk geometri) untuk sekolah dasar dijelaskankan bahwa pembelajaran hendaknya diawali dengan pengenalan masalah yang sesuai dengan situasi (contextual problems), yang secara berangsur dibimbing untuk menguasai konsep geometri.

Salah satu pendekatan pembelajaran matematika (termasuk geometri) yang menekankan penggunaan masalah kontekstual sebagai titik awal pembelajaran adalah Realistic Mathematics Education (RME). Di mana RME ini berasal dari kerajaan Belanda (Institut Freudenthal Universiti Utrecht), yang kemudian diadaptasi oleh Indonesia menjadi Pendidikan Matematika Realistik Indonesia (PMRI), yaitu RME yang disesuaikan dengan kondisi, alam, sistem sosial, dan budaya Indonesia termasuk budaya Minangkabau di Sumatera Barat khusus di Kota Padang (Robert Sembiring, 2010; Suryanto et al. 2010).

Realititas yang ada di sekolah, termasuk di sekolah dasar pembelajaran geometri masih didominasi oleh guru dalam bentuk ceramah (berpusat pada guru), dan belum dimulai dari masalah kontekstual, hingga pelajar dalam kondisi pasif dalam mengikuti pembelajaran di kelas. Berdasarkan dapatan hasil kajian pendahuluan di sekolah dasar ( Ahmad, 2013) pada materi geometri, peneliti menemukan bahwa guru masih tetap saja kembali mengajar secara konvensional atau secara tradisional, sehingga pelajar cenderung pasif dan menghafal rumus-rumus (formulaformula) saja dalam geometri. Guru juga langsung memberikan drillinformasi (pemberian latihan) tentang suatu konsep bentuk geometri (Ipung Yuwono, 2006; Heruman, 2010). Kondisi pembelajaran seperti ini berpengaruh tidak baik kepada penguasaan dan pemahaman siswa terhadap konsep geometri di sekolah dasar. Hal ini dukung oleh Mei- Yan Chan (2007) :

$$
\text { Conventional practice of primary }
$$
mathematics teaching usually focuses on teaching students how to perform calculation. But the spiral bianshi curriculum is designed in a way that emphasizes on helping students construct mathematical concepts and apply the concepts to a wider variety of contexts.

Dari kutipan itu diinformasikan bahwa praktek pembelajaran konvensional di sekolah rendah lebih memfocuskan kepada perhitungan (kalkulasi) dari pada penanaman konsepnya.

Lebih lanjut Peneliti melaporkan dalam temuan penelitian pendahuluannya pada topik geometri yang pertanyaannya berhubungan dengan keliling dan luas geometri datar, serta juga dihubungkait dengan peringkat berfikir geometri model van Hiele didapati bahwa skor rata-rata siswa sekolah dasar yang kategori berada pada peringkat atas (high level) dan tengah (middle level) di Bandar Padang Provinsi Sumatera Barat Indonesia masih saja di bawah skor Kriteria Kelulusan Minimal (KKM) yang ditetapakan sekolah. Apalagi siswa yang berada pada sekolah rendah yang peringkat sekolahnya berada di posisi bawah (low level) maka skornya lebih rendah lagi. Nur'aeni (2010) telah menyimpulkan dalam temuan penelitiannya bahwa kompetensi pemahaman konsep geometri model berfikir van Hiele siswa sekolqh dasar yang diajar dengan pendekatan konvensional atau tradisional tergolong rendah. Oleh karena itu, perlu dikaji dan dikembangkan suatu pendekatan atau model pembelajaran yang akan dapat meningkatkan kualitas proses pembelajaran geometri di sekolah dasar yang ada di kota Padang Provinsi Sumatera Barat Indonesia.

Menurut Joiyce dan Weil (2000) bahwa model pembelajaran adalah merupakan suatu perencanaan atau pola dimana dengan hal itu guru boleh membantu siswa untuk mendapatkan atau memperoleh tujuan, ide, kemahiran, cara berfikir dan menyatakan ide mereka. Selain itu guru juga mengajarkan bagaimana siswa itu belajar. Sementara itu menurut Trianto (2011), model pembelajaran merupakan suatu perancangan atau skim yang digunakan sebagai garis panduan untuk merancang proses pembelajaran di dalam kelas dan untuk menentukan bahan pembelajaran seperti 
buku teks (bahan ajar), kurikulum dan sebagainya. Lebih lanjut Eggen, P dan Kauchak, D (2012) menjelaskan pula bahwa model pembelajaran adalah pendekatan khusus dalam pembelajaran yang mempunyai tiga ciri, iaitu (1) tujuan : model pembelajaran dibuat untuk membantu pelajar membangun kemampuan berpikir kritis dan memperoleh pemahaman mendalam mengenai bentuk khusus topik pembelajaran,(2) tahapan : model pembelajaran mempunya beberapa langkahlangkah (syntax) dan sering disebut "fase"dengan tujuan membantu pelajar mencapai tujuan pembelajaran yang khusus, dan (3) fondasi : model pembelajaran didukung oleh teori dan penelitian mengenai pembelajaran, termasuk geometri.

Adalah sangat penting untuk merekabentuk model pembelajaran yang inovatif disebabkan keperluan guru dalam membantu pelajar untuk belajar konsep matematik secara mudah khususnya berkenaan dengan Geometri. Sehingga kini, model yang diimplementasikan dalam kelas adalah teacher centered dan bahan pembelajaran tidak berhubungkait dengan pengalaman nyata pelajar. Akibatnya prestasi belajar siswa dalam topik geometri masih rendah. Hal ini terjadi disebabkan seperti yang dijelaskan oleh Battista, M.T, (2000) dan Mitchelemore, M, (2002) bahwa pembelajaran geometri tidaklah mudah dan kebanyakan siswa gagal untuk memahami konsep geometri, berfikir geometri dan dalam menyelesaikan masalah geometri.

Salah satu pembelajaran dalam subjek geometri yang berorientasikan kepada aplikasi matematika dalam situasi kehidupan nyata siswa adalah pembelajaran dengan pendekatan pendidikan matematika realistik (Ary Wijaya,2012), yang di sekolah negara Indonesia disebut dengan pendidikan matematika realistik Indonesia (PMRI). Berdasarkan pengamatan, diyakini bahwa pendekatan ini sesuai dengan paradigma dalam pengajaran dan pembelajaran yaitu peralihan daripada fokus pengajaran kepada fokus pembelajaran yang lebih mengaktifkan siswa. Untuk itu perlu dikembangkan suatu model pembelajaran geometri menggunakan pendekatan pendidikan matematik realistik Indonesia (PMRI). Di sekolah dasar negara Indonesia, khusunya di Kota Padang model pembelajaran geometri yang menggunakan pendekatan pembelajaran pendidikan matematika realistik Indonesia (PMRI) saat ini belum dikembangkan secara maksimal . Penelitian ini dilaksanakan bertujuan untuk: (1) mengembangkan model pembelajaran geometri dengan menggunakan pendekatan PMRI yang memenuhi kriteria valid, praktis dan efektif (2) membandingkan perbedaan keberkesanan (keefektifan) model terhadap hasil belajar dalam tajuk geometri berdasarkan peringkat pemahaman model van Hiele antara sebelum dan selepas menggunakan Pendekatan Pengajaran Pendidikan Matematika Realistik Indonesia (PMRI).

\section{METODOLOGI PENELITIAN}

Penelitian ini merupakan penelitian pengembangan (development research). Adapun yang dikembangkan dalam riset (penelitian) ini adalah model pembelajaran geometri di sekolah dasar di kota Padang berpendekatan pendidikan matematika realistik (PMRI) yang valid, praktis dan berkesan (efektif). Penelitian ini telah dilaksanakan di sekolah dasar negeri (SDN) No. 14 Gurun Laweh kota Padang, dengan subjek penelitian siswa kelas IV yang berjumlah 33 orang (one-group).

Teknik pengumpulan data dilaksanakan dengan menggunakan observasi,wawancara, angket, dan tes. Adapun instrumen penelitian yang digunakan adalah lembar observasi, pedoman wawancara, lembar angket untuk siswa, soal-soal penilaian hasil belajar, lembar validasi model pembelajaran yang dikembangkan.

Untuk melihat keefektifan Model yang dihasilkan setelah divalidasi oleh validator, Model Pembelajaran Geometri ini diuji cobakan pada salah satu sekolah di kota Padang yang merupakan sekolah mitra PMRI yaitu SDN NO. 14 Gurun Laweh Padang, Sumatera Barat Indonesia. Jenis eksperimen ini berbentukTimes Series Experimental Designs. Variabel utama adalah hasil pembelajaran Matematika siswa dalam hal ini 
topik geometri (Sugiyono: 2011). Alasan pengkaji memilih rancangan eksperimen di atas, karena peneliti hanya memiliki akses ke satu kelompok saja dan hanya meneliti pada periode tertentu. Dengan demikian maka pendekatan yang sesuai adalah desain rangkaian waktu/ time series. Desain time-series ini merupakan kajian terhadap satu kelompok saja, dalam jangka waktu tertentu, dan dengan beberapa pretes dan postes untuk pengukuran dan observasi yang dibuat oleh peneliti (Creswel, 2012). Adapun pola rancangannya ditunjukkan pada Tabel 1. di bawah ini.

Tabel 1 : Rancangan Times Series Experimental Designs

\begin{tabular}{|c|c|c|}
\hline PreTest & Perlakuan & PostTest \\
$\mathrm{O}_{1}$ & $\mathrm{X}_{1}$ & $\mathrm{O}_{4}$ \\
$\mathrm{O2}$ & $\mathrm{X2}$ & $\mathrm{O5}$ \\
$\mathrm{O3}$ & $\mathrm{X3}$ & O6 \\
\hline
\end{tabular}

\section{Keterangan : \\ $\mathrm{O}_{1} \mathrm{O}_{2} \mathrm{O}_{3}=$ Nilai pretest sebelum perlakuan sebanyak $3 \mathrm{kali}$ \\ $\mathrm{X}_{1} \mathrm{X}_{2} \mathrm{X}_{3}=$ Perlakuan dengan menggunakan model pembelajaran geometri dengan pendekatan PMRI. \\ $040506=$ Nilai posttest setelah diberi perlakuan sebanyak 3 kali}

Ketentuan ini dipilih untuk melihat keberkesanan (efektifitas) model terhadap hasil pembelajaran dalam topik geometri berdasarkan tahapan peringkat berfikir model van Hiele antara sebelum dan sesudah menggunakan pendekatan pembelajaran pendidikan matematika realistik Indonesia (PMRI). Untuk melihat pengaruh penggunaan model pembelajaran geometri berasas PMRI ini di analisis dengan Anova satu Jalur melalui program Statistical Package for Social Science (SPSS versi 2016). Lebih lanjut untuk mendalami pemahaman siswa dalam konsep geometri perlu digali dengan instrumen wawancara. Wawancara dilakukan terhadap pemahaman siswa dalam peringkat berfikir van Hiele sesudah pelaksanaan eksperimen model One Group peretest-postest design.

\section{HASIL PENELITIAN DAN PEMBAHASAN}

\section{Hasil Penelitian.}

Mengacu pada rumusan masalah penelitian ini yaitu : (1) bagaimana proses pengembangan model pembelajaran geometri berpendekatan Pendidikan matematika realistik Indonesia (PMRI) di sekolah dasar yang valid, praktis, dan berkesan?, serta (2) adakah terdapat perbedaan keberkesanan model terhadap hasil pembelajaran belajar dalam tajuk geometri berdasarkan peringkat pemahaman model van Hiele antara sebelum dan sesudah menggunakan Pendekatan Pendidikan Matematika Realistik Indonesia (PMRI)?, dapat dipaparkan hasil penelitian sebagai berikut.

Proses pengembangan model, dan perangkat pembelajaran geometri berpendekatan PMRI yang valid, praktis dan berkesan (efektif).

Proses pengembangan model, dan perangkat pembelajaran geometri berpendekatan PMRI ini mengacu pada model yang dikembangkan oleh Tjeerd Plomp (baca Musdi, 2012), yang meliputi 4 fase yaitu: (1) fase penjajakan/investigasi awal, (2) perancangan model pembelajaran geometri, realisasi/konstruksi model, (4) pengujian, evaluasi dan revisi. Dari penjajakan/investigasi awal yang peneliti lakukan di beberapa sekolah dasar mitra jurusan PGSD FIP UNP baik melalui tes hasil belajar geometri siswa di kelas 4 (riset pendahuluan), wawancara dengan guru kelas serta observasi langsung ke dalam kelas, diperoleh informasi bahwa guru belum menggunakan model pembelajaran berpendekatan pendidikan matematika realistik (PMRI). Di samping itu proses pembelajaran yang dilaksanakan berpusat pada guru (teacher centred), dalam pembelajaran geometri guru langsung memberikan rumus-rumus 
dari suatu geometri. Tambahan pula siswa lebih bersifat pasif dan hanya diminta menghafal rumusrumus. Data hasil belajar siswa pada pemahaman konsep geometri juga masih rendah. Rata-rata hasil belajar siswa pada geometri tersebut semua sekolah yang dijajaki masih di bawah Kriteria Ketuntasan Minimal (KKM) yakni di bawah skor 75 .

Berdasarkan data yang diperoleh dari penjajakan/investigasi/riset awal itu dirancang/didesain suatu model pembelajaran yang dilengkapi dengan perangkat pembelajaran berpendekatan pendidikan matematika realistik Indonesia (PMRI) dalam bentuk buku. Setelah buku model dirancang dan disusun, tahap berikutnya dinilai oleh pakar (ahli) untuk melihat validitas model yang dikembangkan. Para pakar di sini dimaksudkan pakar matematika bebasis ke SD-an , PMRI, dan bahasa Indonesia. Setelah itu dilakukan revisi sesuai dengan saran-saran validator, dimana ada beberapa saran yang harus direvisi misalnya dalam rancangan pembelajaran harus tergambar kombinasi PMRI dengan langkahlangkah van Hiele, kemudian harus tampak komponen kontribusi siswa pada penerapan prinsip PMRI dalam pembelajaran. Tambahan lagi pada poin penilaian disarankan ada unsur kognitif, afektif dan psikomotor. Kemudian setelah direvisi model yang sudah divalidasi dan dinyatakan layak untuk digunakan di lapangan, maka tahap berikutnya peneliti melakukan uji coba di salah satu sekolah dasar di kecamatan Lubuk Begalung Kota Padang, yaitu SDN NO.14 Gurun Laweh Padang. Sebelum diuji coba peneliti melatih guru kelas 4 tentang penerapan model pembelajaran yang akan diimplementasikan di kelas.Uji coba dilaksanakan dengan penelitian eksperimen berdesain time-series one grou pretest and postest . Perlakuan dilaksanakan sebanyak tiga kali dengan tiga kali pretest, tiga kali perlakuan, serta tiga kali postest.

Untuk menentukan efektifitas PMRI terhadap prestasi siswa dalam geometri, maka data-data harus dianalisis dengan menggunakan tes ANOVA. Terlebih dahulu data-data untuk variabel bersandar perlu diuji kenormalan data terlebih dahulu dengan menjalankan tes kenormalan (Normalitas Test). Analisa ini dilaksanakan untuk menentukan bahwa keseluruhan data responden yang diperoleh adalah "well-modelled", yaitu apakah data yang diperoleh tersebar secara distribusi normal atau tidak. Untuk mendapatkan hasil untuk analisa ini, tes kenormalan dilakukan pada keseluruhan data responden yang ada. Untuk tujuan ini, tes Shapiro-Wilk digunakan untuk mengukur kenormalan data karena ini sesuai untuk digunakan untuk ukuran sampel yang kurang dari 50 orang (Shapiro dan Wilk, 1965). Selain itu, tes ini juga lebih efisien dibandingkan tes-tes lain seperti tes Lilliefors, Kolmogorov - Smirnov dan Anderson - Darling ( Razali dan Wah, 2011). Tabel 2 menunjukkan temuan tes kenormalan data untuk variabel bersandar dalam penelitian ini. Nilai signifikan tes kenormalan Shapiro-Wilk untuk tes geometri adalah .247, .054 dan .007. Oleh karena nilai-nilai ini lebih besar dari nilai alpha 0,05 , maka hipotesis nol di terima. Jadi, temuan ini menunjukkan bahwa data untuk tes geometri adalah tersebar secara normal.

Tabel 2: Analisis ujian kenormalan bagi ujian geometri 01,02 dan $\mathrm{O3}$

\begin{tabular}{|l|c|c|c|c|c|c|}
\hline & \multicolumn{3}{|c|}{ Kolmogorov-Smirnov $^{\boldsymbol{a}}$} & \multicolumn{3}{c|}{ Shapiro-Wilk } \\
\cline { 2 - 7 } & Statistic & $\boldsymbol{d f}$ & Sig. $^{*}$ & Statistic & $\boldsymbol{d f}$ & Sig. \\
\hline Ujian Geometri O1 & .110 & 33 & $.200^{*}$ & .959 & 33 & .247 \\
\hline Ujian Geometri O2 & .174 & 33 & .013 & .937 & 33 & .054 \\
\hline Ujian Geometri O3 & .194 & 33 & .003 & .905 & 33 & .007 \\
\hline
\end{tabular}

Kemudian, analisis ANOVA satu arah pengukuran berulang dilaksanakan untuk membandingkan skor untuk ketiga-tiga set data tes geometri yang dikumpulkan pada tingkat $\mathrm{O} 1, \mathrm{O} 2$ dan O3. Jadi, hipotesis untuk tes ANOVA adalah seperti berikut: 
Ho: Tidak ada perbedaan yang signifikan antara nilai min skor bagi set tes geometri saat $\mathrm{O} 1, \mathrm{O} 2$ dan $\mathrm{O} 3$

H1: Ada perbedaan yang signifikan antara nilai min skor bagi set tes geometri saat $\mathrm{O} 1, \mathrm{O} 2$ dan $\mathrm{O} 3$

Berdasarkan tes geometri yang diberikan sebelum dan setelah siswa menggunakan PMRI, Tabel 3 menunjukkan analisis deskriptif yang diperoleh dari tes geometri saat $\mathrm{O} 1, \mathrm{O} 2$ dan $\mathrm{O} 3$ dengan jumlah siswa sebanyak 33 orang. Berdasarkan Tabel 3, ditemukan bahwa nilai min untuk tes geometeri saat $\mathrm{O} 1$ adalah 45.15 dengan nilai standar deviasi 14.169. Selain itu, nilai min untuk tes geometeri saat $\mathrm{O} 2$ adalah 54.24 dengan nilai standar deviasi 16.776. Sedangkan untuk tes geometri saat $\mathrm{O} 3$, ditemukan nilai min menunjukkan 47.73 dengan nilai standar deviasi 16.446. Secara keseluruhan ditemukan bahwa skor tes geometri saat $\mathrm{O} 2$ menunjukkan nilai min yang tertinggi dibandingkan skor yang diperoleh saat $\mathrm{O} 1$ dan $\mathrm{O} 3$.

Tabel 3: Statistik Deskriptif bagi Ujian Geometri

\begin{tabular}{|l|c|c|c|}
\hline & Min & Simpangan baku & N \\
\hline ujianGeometri_O1 & 45.15 & 14.169 & 33 \\
ujianGeometri_O2 & 54.24 & 16.776 & 33 \\
ujianGeometri_O3 & 47.73 & 16.446 & 33 \\
\hline
\end{tabular}

Tabel 4 menunjukkan empat tes multivariate dalam kelompok yang menunjukkan nilai $\mathrm{F}$ yang sama.Walau bagaimanapun, temuan menunjukkan bahwa nilai signifikan (nilai $p$ ) adalah .000, kurang dari nilai alpha, .005, ini menunjukkan bahwa ada perbedaan yang signifikan di dalam skor di antara tiga set tes geometri. Nilai Wilk $\mathrm{s}$ Lambda - $\mathrm{p} \quad<0,05$ menunjukkan bahwa ada perbedaan yang signifikan di dalam ketiga skor geometri. Menurut Cohen (1988), nilai ukuran efek $.01=$ efek yang kecil, $0.6=$ efek yang sederhana, $.14=$ efek yang besar. Jadi, berdasarkan Tabel 5.3, ditemukan bahwa nilai ukuran efek dari studi ini adalah .56 yang menunjukkan nilai ukuran efek yang besar. Sebagai kesimpulan, temuan ANOVA menunjukkan bahwa terdapat perbedaan yang signifikan di antara tiga set tes geometri dengan Wilk s Lambda .439, F $(2,31)=19.81, \mathrm{P}=.000$. Jadi, analisis tes T-berpasangan dilakukan dengan koreksi Bonferroni digunakan.

Tabel 4: Ujian Multivariate dalam Kumpulan bagi Ujian Geometri

\begin{tabular}{|l|c|c|c|c|c|c|c|c|}
\hline Effect & Value & $\mathrm{F}$ & Hypothesis df & Error df & Sig. & $\begin{array}{c}\text { Partial Eta } \\
\text { Squared }\end{array}$ & $\begin{array}{c}\text { Noncent. } \\
\text { Parameter }^{\text {Oabserved }}\end{array}$ & $\begin{array}{c}\text { Power } \\
{ }^{\mathrm{c}}\end{array}$ \\
\hline Pillai's Trace & .561 & $19.816^{\mathrm{b}}$ & 2.000 & 31.000 & .000 & .561 & 39.631 & 1.000 \\
\hline Wilks' Lambda & .439 & $19.816^{\mathrm{b}}$ & 2.000 & 31.000 & .000 & .561 & 39.631 & 1.000 \\
\hline Hotelling's Trace & 1.278 & $19.816^{\mathrm{b}}$ & 2.000 & 31.000 & .000 & .561 & 39.631 & 1.000 \\
\hline Roy's Largest Root & 1.278 & $19.816^{\mathrm{b}}$ & 2.000 & 31.000 & .000 & .561 & 39.631 & 1.000 \\
\hline
\end{tabular}

Jadi, Tabel 5 menunjukkan bahwa tidak ada perbedaan yang signifikan antara skor untuk tes geometri saat $\mathrm{O} 1$ dan tes geometri saat $\mathrm{O} 3(\mathrm{t}$ $(32)=-927, p=.361)$. Namun, ada perbedaan yang signifikan antara skor tes geometeri saat $\mathrm{O} 1$ dan skor tes geometeri saat $\mathrm{O} 2(\mathrm{t}(32)=-4.778, \mathrm{p}=$
.000). Ada perbedaan yang signifikan juga terlihat di antara skor tes geometri saat $\mathrm{O} 2$ dan skor tes geometri saat $\mathrm{O} 3(\mathrm{t}(32)=3.618, \mathrm{p}=.001)$. Temuan ini menunjukkan bahwa ada perubahan signifikan dalam skor tes geometri siswa setelah menggunakan PMRI. 
Tabel 5 : Ujian T-Berpasangan bagi ujian geometri sewaktu O1, 02 dan 03

\begin{tabular}{|c|c|c|c|c|c|c|c|c|c|}
\hline & \multicolumn{5}{|c|}{ Paired Differences } & \multirow{3}{*}{$\mathrm{T}$} & \multirow{3}{*}{ Df } & \multirow{3}{*}{$\begin{array}{l}\text { Sig. (2- } \\
\text { tailed) }\end{array}$} \\
\hline & & \multirow[t]{2}{*}{ Mean } & \multirow{2}{*}{$\begin{array}{c}\text { Std. } \\
\text { Deviation }\end{array}$} & \multirow{2}{*}{$\begin{array}{l}\text { Std. Error } \\
\text { Mean }\end{array}$} & \multicolumn{2}{|c|}{$\begin{array}{l}95 \% \text { Confidence Interval of } \\
\text { the Difference }\end{array}$} & & & \\
\hline & & & & & Lower & Upper & & & \\
\hline Pair 1 & $\begin{array}{l}\text { ujianGeometri_O1 - } \\
\text { ujianGeometri_O2 }\end{array}$ & -9.091 & 10.930 & 1.903 & -12.966 & -5.215 & -4.778 & 32 & .000 \\
\hline Pair 2 & $\begin{array}{l}\text { ujianGeometri_O2 - } \\
\text { ujianGeometri_O3 }\end{array}$ & 6.515 & 10.344 & 1.801 & 2.847 & 10.183 & 3.618 & 32 & .001 \\
\hline Pair 3 & $\begin{array}{l}\text { ujianGeometri_O1- } \\
\text { ujianGeometri_O3 }\end{array}$ & -2.576 & 15.965 & 2.779 & -8.237 & 3.085 & -.927 & 32 & .361 \\
\hline
\end{tabular}

Dengan melihat paparan data pada tabel tabel di atas dapat dikatakan bahwa terdapat perbedaan signifikan hasil belajar geometri antara sebelum dan sesudah menggunakan model pembelajaran geometri berpendekatan PMRI . Dengan diperolehnya data tesebut dapat disimpulkan bahwa model yang sudah diujicoba tersebut sangat efektif digunakan dalam pembejaran geomerti di sekolah dasar. Data ini diperkuat pula dengan hasil wawancara dengan beberapa siswa subjek penelitian tentang pemahaman mereka mengenai konsep geometri dengan sifat-sifat bangun datar yang melekat pada materi penelitian yaitu tentang sifat-sifat bangun datar seperti segitiga, persegi, pesegi panjang, dan jajar genjang. Temuan yang menonjol dan menarik disini siswa sudah dapat memahami bahwa persegi merupakan persegi panjang yang keempat sisinya sama panjang. Tambahan pula bahwa sifat-sifat jajar genjang terdapat pada persegi dan persegi panjang, sehingga mereka dapat menyimpulkan bahwa persegi dan persegi panjang juga termasuk jajar genjang.

\section{Pembahasan}

Berdasarkan hasil penelitian, bahwa model pembelajaran geometri berpendekatan PMRI yang telah di desain dan di validasi oleh pakar (validator) telah valid, dan praktis, meskipun melalui revisi pada beberapa komponen. Model ini dapat menjadi pedoman atau garis panduan yang dijadikan oleh guru sebagai acuan atau contoh dalam pembelajaran geometri. Dari implementasi di lapangan ditemukan bahwa model yang sudah dibina itu telah berkesan (efektif), dapat mengaktifkan siswa, serta siswa dapat mengkonstruksi sendiri (reinvention) konsep geometri. Salah satu yang menonjol saat pelaksanaan pembelajaran adalah siswa dapat menyimpulkan (tahap deduksi informal) bahwa persegi merupakan persegi panjang yang semua sisinya sama panjang. Tambahan pula bahwa persegi dan persegi panjang termasuk bangun datar jajar genjang. Temuan ini sejalan dengan pendapat Gavemaijer, 1994 tentang prinsip dan dampak dalam PMRI (baca : Suryanto et al, 2010) yaitu : (1) penemuan kembali (reinvention) secara terbimbing dan upaya yang mengarah kepemikiran matematik, (2) pembelajaran yang bersifat mendidik, dan (3), membangun sendiri model matematik, dalam hal ini geometri.

Tambahan pula dari implementasi model tersebut dapat menggiring siswa pada tahap berpikir geometri model van Hiele mulai dari tahap visualisasi, penentuan sifat-sifat bangun datar, dan tahap pengambilan kesimpulan secara induktif. Hal ini terbukti siswa-siswa telah dapat menentukan sifat-sifat dari suatu segitiga, persegi, persegi panjang, dan jajar genjang sesuai dengan kurikulum KTSP kelas 4 sekolah dasar. Hal ini sejalan dengan teori van Hiele ( baca : Kennedy, 2008; Freitag, MA, 2014) bahwa model tahapan peringkat berfikir geometri van Hiele, yaitu (1) tahap 0 (visualisasi), (2) tahap 1 (pengenalan sifat), (3) tahap 2 (pengambilan kesimpulan secara informal), (4) tahap 3 (deduksi), dan (5) tahap 4 (rigor/akurasi). Khusus untuk sekolah dasar hanya dituntut untuk membangunkan tiga tahapan peringkat berfikir yaitu tahapan 0 (visualisasi), tahap 1 (pengenalan sifat), dan tahapan 2 
(pengambilan kesimpulan secara informal), sedangkan untuk dua peringkat berfikir berikutnya dibangunkan di level sekolah menengah dan level pendidikan tinggi.

\section{SIMPULAN DAN SARAN}

Hasil penelitian menunjukkan bahwa model pembelajaran geometri berpendekatan PMRI yang telah dibina atau dikembangkan di sekolah dasar telah memenuhi kriteria kevalidan, kepraktisan dan keberkesanan. Dari hasil ujicoba lapangan berdesain penelitian eksperimen model time series one group pretest and postest terbukti ampuh untuk meningkatkan hasil belajar geometri siswa sekolah dasar. Di samping itu model pembelajaran yang dikombinasikan atau "dikawinkan"antara PMRI dan model van Hiele, terbukti telah dapat meningkatkan taraf berpikir siswa pada peringkat tiga model van Hiele ( tahap deduksi informal) .

Bertitik tolak dari kesimpulan di atas, disarankan kepada guru di sekolah dasar dalam pembelajaran geometri menggunakan model yang sudah dihasilkan ini, karena terbukti ampuh dalam meningkatkan hasil belajar dan pemahaman siswa dalam mempelajari geometri.

\section{DAFRTAR PUSTAKA}

Ahmad, Syafri. 2013. Kefahaman konsep geometri siswa sekolah dasar Kota Padang. Penelitian pedahuluan. Padang: Tidak diterbitkan.

Ahmad, Syafri.2011. Inovasi Pembelajaran Sistem Koordinat Cartesius bagi siswa Kelas VI Sekolah Dasar. Pedagogi, Volume IX No. 01. 1 Apri 2011 hal.123-137.

Alex J.K and J Mammen. 2012. A Survey of South African Grade10 Learner's Geometric Thinking Levels in Terms of the Van Hiele Theory. Journal Antrhropologist 14 (2): 123-129,

Ariadi Wijaya. 2012. Pendidikan Matematika Realistik; Suatu Alternatif Pendekatan
Pembelajaran Matematika. Yokyakarta: Graha Ilmu

Ary, Donal, Jakop, Lucy Cheser, dan Ashegar Raswieh. 1985. Introduction to Research in Education. New York : Rinehard dan Wiston

Battista, M.T ( 2000). Geometry Result from the Third International Mathematics and Science Study. Teaching Children Mathematics, 5 (6), 367-373.

Bell, Max. 2004. Every Day Mathematics.. USA : SRA/ Mc Graw-Hill BOLEMA-MATHEMS EDUCATION BULLETIN-BOLETIM DEEDUCACAO MATEMATICA Volume: 22(22) 81-104

Chang, Kuo-En; Sung, Yao-Ting;and Lin, SongYing.2007. Developing geometry thinking through multimedia learning activities.COMPUTERS IN HUMAN BEHAVIOR Volume: 23(5) 2212-2229

Cohen,Y, J. (1988). Statistical Power Analysis For The Behavior Science. Lawrance Eribaum Association.

Creswell, John W. 2012. Educational Research. Pearson: United States of America.

D.Gall, Meredith: P. Gall, Joyce and R.Borg, Walter. 2003. Educational Research An Introduction. Boston :Allyn and Bacon.

Depdiknas, 2006. Standar Isi Mata Pelajaran Matematika untuk Sekolah Menengah $\operatorname{Atas}(S M A) \cdot$ http://www.puskur.net/inc/si/s $\underline{\text { ma/matematika.pdf. Diakses tanggal } 1}$ Maret 2007.

Depdiknas. 2006. Kurikulum Tingkat Satuan Pembelajaran. Pusat Kurikulum Balitbang, Depdiknas. Jakarta 
Eggen, Paul dan Kauchak ,Don (2012). Strategie and models for Teacher : Teaching Content and Thinking Skills. Boston : Pearso Education Inc.

Erbas , Ayhan Kursat dan Yenmez Arzu Aydogan $^{\mathrm{a}}$ The effect of inquiry-based explorations in a dynamic geometry environment on sixth grade studn ents' achievements in polygons Computers \& EducationVolume 57, Issue 4, December 2011, Pages 2462-2475

Freitag, M.A. 2014. Mathematatics for Elementary School Teachers. A Proses approach. USA : Brooks.

French, D. (2004). Teaching and learning geometry. London: Continuum

Harun, M. 2014. Membantu Anak Menguasai Geometri, Menumbuhkembangakan Kepekaan Ruang. Padang : Suka Bina Press

Heruman.2010. Model Pembelajaran Matematika di Sekolah Dasar.Bandung: Rosda K.

Hudoyo, H. (2000). Pembelajaran Matematika di Sekolah. Malang : FMIPA UM Malang

Ipung Yuwono. 2006. Pengembangan Model Pembelajaran Matematika Secara Membumi. Surabaya : Disertasi Tidak diterbitkan.

Joyce, Bruce and Weil,Marsha. 2000.Models of Teaching. Ed.Boston: Allyn \& Bacon

Kennedy, L.M, Tipps, S, and Art Johson. 2008. Guiding Children's Learning of Mathematics. U.S.A : Thomson.

Marchis, Iuliana. 2012. Preservice Primary School Teachers'Elementary Geometry
Knowledge. Journal Acta Didactica Napocensia, Volume 5 Number 2

Matematika SD dan MIN. Jakarta; Balitbang Depdiknas.

Mei Anna- Yan chan. 2007.The effects of spiral bianshicurriculum: A case study of the teaching of speed for Primary 6 students in Hong Kong. Proceeding. The fourth East Asia Regional Conference on Mathematics Education (EARCOME4)

Mitchelemore, M. 2002. The Role of Abstractions and Generalisation in development of mathematics knowledge. USA : Mc graw Hill

Musdi,E. 2012. Pembelajaran Geometri dan RME di SMPN Kota Padang . Padang: Universitas Negeri Padang.

Nur'aeni, E. 2010. Pengembangan Kemampuan Pemahaman dan Komunikasi Matematis Siswa Sekolah Dasar Melalui Pembelajaran Geometri Berbasis $\mathrm{H}$ Teori Van Hiele. Bandung: Disertasi Tidak diterbitkan.

Pitajeng.2006. Pembelajaran Matematika yang menyenangkan. Jakarta : Depdiknas

Plomp, Tjeerd., 1997. Educational and Training System Design. Enschede. The Netherland: University of Twente.

Presmeg, N. (2006). Research on visualization in learning and teaching mathematics. InA.Gutierrez \& P.Boero (Eds.), Handbook of Research on the Psychology of MathematicsEducation: Past, Present and Future (pp. 205-236). Sense Publishers. 
Razali, M, N., dan Wah, Y. B. (2011). Power comparisons of Shapiro-Wilk, Kolmogorov-Smirnov, Lilliefors and Anderson-Darling tests. Journal of Statistical Modeling and Analytics, 2(1), 21-33.

Rusman. 2011. Model-Model Pembelajaran. Mengembangkan Profesionalisme Guru. Jakarta : PT. Raja Grafindo Persada.

Sa'dijah, Cholis.2001. Pendidikan Matematika II. Jakarta: Depdikbud

Sarjiman, P. 2012. Peningkatan Pemahaman Rumus Geometri melalui Pendekatan Matematika Realistik di SD. Hompage $\mathrm{http} / /$ :

penelitiantindakankelas.blogspot.com.

Diakses 30 Mei 2014.

Schwartz, J.E. 2008. Elementary Mathematics pedagogical content Knowledge. Pearson Allyn Bacon.

Sembiring,R.,Hoogland, K. And Dolk,M. 2010. A Decade Of PMRI inIndonesia. Utrecht: Ten Brink MEPPEL.
Shapiro, S. S dan Wilk, M. B. (1965). An analysis of variance test for normality. Biometrika, $52(3 / 4), 591-611$

Sugiyono. 2011. Metodologi Penelitian Pendidikan. Bandung: Alfabeta.

Suryanto: Ahmad Fauzan: Ponta Hutagalung: R K Sembiring. 2010. Sejarah Pendidikan Matematika Realistik Indonesia(PMRI). Yokjakarta: PMRI pusat

Sutawijaya, Akbar; Muhsetyo, G; A. Karim, Mukhtar; Soewito. 2001. Pendididan Matematika III. Jakarta: Depdikbud.

Trianto.2011.Mendesain Model Pembelajaran Inovatif-Progresif. Jakarta : Kharisma Putra Utama

Van De Walle, Jhon A.2008. Elementary School Mathematics. Teaching Developmentally. New York \& London: Longman Publishing Group 